Ghidini Alessandro (Orcid ID: 0000-0002-6662-1630)

Levy Brynn (Orcid ID: 0000-0002-4213-3480)

Deprest Jan (Orcid ID: 0000-0002-4920-945X)

Van Mieghem Tim (Orcid ID: 0000-0002-3034-6905)

Chitty Lyn (Orcid ID: 0000-0002-4857-7138)

Hui Lisa (Orcid ID: 0000-0002-9720-3562)

Editorial

Diana W. Bianchi, Alessandro Ghidini, Brynn Levy, Jan Deprest, Tim van Mieghem, Lyn S. Chitty, Lisa Hui, Amanda McLean-Inglis

\title{
The 2018 Malcolm Ferguson-Smith Young Investigator Award
}

In recognition of Prenatal Diagnosis' Founding Editor, Professor Malcolm Ferguson-Smith, the Young Investigator Award honors the best article published in the journal during the previous calendar year with a first author under the age of 40 years.

This year, we had a very strong field from which to choose our winner and runners-up. We received 22 worthy nominations, from which we created a shortlist of four potential winners. The editors then ranked the shortlisted papers and the scores were collated. Our usual policy applied; any editor who is a co-author on a nominated paper does not rank the paper in question due to the inherent conflict of interest.

It is with great pleasure that the Editors and Publisher of Prenatal Diagnosis announce that Karen Stals (Figure 1) is the winner of the 2018 Award for her paper entitled Diagnosis of lethal or prenatal-onset autosomal recessive disorders by parental exome sequencing, published in the January 2018 issue of the journal [1].

\{picture of Karen Stals - separate doc\}

Figure 1. Karen Stals, winner of the 2018 Malcolm Ferguson-Smith Young Investigator Award

The runner-up, in second place, is Nathalie Brison for Predicting fetoplacental chromosomal mosaicism during noninvasive prenatal testing [2], published in the March issue.

Third place is awarded to Molka Kammoun for Genetic profile of isolated congenital diaphragmatic hernia revealed by targeted next-generation sequencing [3], published in the August issue.

Our fourth-place runner-up is Zhiyong Zou, for Unusual twinning: Additional findings during prenatal diagnosis of twin zygosity by single nucleotide polymorphism (SNP) array [4], from our May issue.

All prior winners of the Award are shown in Table 1.

This is the author manuscript accepted for publication and has undergone full peer review but has not been through the copyediting, typesetting, pagination and proofreading process, which may lead to differences between this version and the Version of Record. Please cite this article as doi: $10.1002 / \mathrm{pd} .5533$

This article is protected by copyright. All rights reserved. 
Table 1. The Malcolm Ferguson-Smith Award: winning authors and articles

\begin{tabular}{|c|c|c|}
\hline Year & Author & Article title \\
\hline 2018 & Karen Stals, UK & $\begin{array}{l}\text { Diagnosis of lethal or prenatal-onset autosomal recessive disorders by } \\
\text { parental exome sequencing [1] }\end{array}$ \\
\hline 2017 & Victoria Viart, France & $\begin{array}{l}\text { Germline mosaicism is a pitfall in PGD for X-linked disorders. Single } \\
\text { sperm typing detects very low frequency paternal gonadal mosaicism } \\
\text { in a case of recurrent chondrodysplasia punctata misattributed to a } \\
\text { maternal origin [5] }\end{array}$ \\
\hline 2016 & David Barrett, UK & $\begin{array}{l}\text { Connexin } 43 \text { is overexpressed in human fetal membrane defects after } \\
\text { fetoscopic surgery [6] }\end{array}$ \\
\hline 2015 & Suzanne Drury, UK & $\begin{array}{l}\text { Exome sequencing for prenatal diagnosis of fetuses with sonographic } \\
\text { abnormalities [7] }\end{array}$ \\
\hline 2014 & $\begin{array}{l}\text { Nicole Burger and } \\
\text { Kyra Stuurmann, The } \\
\text { Netherlands }\end{array}$ & $\begin{array}{l}\text { Involvement of neurons and retinoic acid in lymphatic development: } \\
\text { new insights in increased nuchal translucency [8] }\end{array}$ \\
\hline 2013 & Amy Metcalfe, Canada & $\begin{array}{l}\text { Impact of observed versus hypothesized service utilization on the } \\
\text { incremental cost of first trimester screening and prenatal diagnosis for } \\
\text { trisomy } 21 \text { in a Canadian province [9] }\end{array}$ \\
\hline 2012 & $\begin{array}{l}\text { Marie Brinch, } \\
\text { Denmark }\end{array}$ & $\begin{array}{l}\text { Identification of circulating fetal cell markers by microarray analysis } \\
\text { [10] }\end{array}$ \\
\hline 2011 & $\begin{array}{l}\text { Jeroen L. A. Pennings, } \\
\text { The Netherlands }\end{array}$ & $\begin{array}{l}\text { Integrative data mining to identify novel candidate serum biomarkers } \\
\text { for pre-eclampsia screening [11] }\end{array}$ \\
\hline 2010 & $\begin{array}{l}\text { Jérôme Toutain, } \\
\text { France }\end{array}$ & $\begin{array}{l}\text { Confined placental mosaicism and pregnancy outcome: a distinction } \\
\text { needs to be made between types } 2 \text { and } 3 \text { [12] }\end{array}$ \\
\hline 2009 & Tianjiao Chu, USA & $\begin{array}{l}\text { A microarray-based approach for the identification of epigenetic } \\
\text { biomarkers for the noninvasive diagnosis of fetal disease [13] }\end{array}$ \\
\hline 2008 & Olivier Picone, France & $\begin{array}{l}\text { Comparison between ultrasound and magnetic resonance imaging in } \\
\text { assessment of fetal cytomegalovirus infection [14] }\end{array}$ \\
\hline 2007 & $\begin{array}{l}\text { Nicholas J. Cowans, } \\
\text { UK }\end{array}$ & $\begin{array}{l}\text { First-trimester ADAM12 and PAPP-A as markers for intrauterine fetal } \\
\text { growth restriction through their roles in the insulin-like growth factor } \\
\text { system [15] }\end{array}$ \\
\hline
\end{tabular}

This article is protected by copyright. All rights reserved. 
Dr. Stals receives $\$ 1,500$ and the opportunity to present her research at the 2019 International Society for Prenatal Diagnosis annual meeting in Singapore (7-11 September 2019).

Details regarding the nomination of papers published in 2019 for the next Malcolm Ferguson-Smith Young Investigator Award will be provided in early 2020.

\section{References}

1 Stals, K. L., Wakeling, M., Baptista, J., Caswell, R., Parrish, A., Rankin, J., Tysoe, C., Jones, G., Gunning, A. C., Lango Allen, H., Bradley, L., Brady, A. F., Carley, H., Carmichael, J., Castle, B., Cilliers, D., Cox, H., Deshpande, C., Dixit, A., Eason, J., Elmslie, F., Fry, A. E., Fryer, A., Holder, M., Homfray, T., Kivuva, E., McKay, V., Newbury-Ecob, R., Parker, M., Savarirayan, R., Searle, C., Shannon, N., Shears, D., Smithson, S., Thomas, E., Turnpenny, P. D., Varghese, V., Vasudevan, P., Wakeling, E., Baple, E. L., and Ellard, S. ( 2018) Diagnosis of lethal or prenatal-onset autosomal recessive disorders by parental exome sequencing. Prenat Diagn, 38: 33-43. doi: 10.1002/pd.5175.

2 Brison, N, Neofytou, M, Dehaspe, L, et al. Predicting fetoplacental chromosomal mosaicism during non-invasive prenatal testing. Prenatal Diagnosis. 2018; 38: 258- 266. https://doi.org/10.1002/pd.5223

3 Kammoun, M, Souche, E, Brady, P, et al. Genetic profile of isolated congenital diaphragmatic hernia revealed by targeted next-generation sequencing. Prenatal Diagnosis. 2018; 38: 654- 663. https://doi.org/10.1002/pd.5327

4 Zou, Z, Huang, L, Lin, S, He, Z, Luo, Y. Unusual twinning: Additional findings during prenatal diagnosis of twin zygosity by single nucleotide polymorphism (SNP) array. Prenatal Diagnosis. 2018; 38: 428- 434. https://doi.org/10.1002/pd.5255

5 Viart, V., Willems, M., Ishmukhametova, A., Dufernez, F., Anahory, T., Hamamah, S., Schmitt, S., Claustres, M., and Girardet, A. (2017) Germline mosaicism is a pitfall in PGD for X-linked disorders. Single sperm typing detects very low frequency paternal gonadal mosaicism in a case of recurrent chondrodysplasia punctata misattributed to a maternal origin. Prenat Diagn, 37: 201-205. doi: $\underline{10.1002 / p d .4982}$

6 Barrett, D. W., David, A. L., Thrasivoulou, C., Mata, A., Becker, D. L., Engels, A. C., Deprest, J. A., and Chowdhury, T. T. (2016) Connexin 43 is overexpressed in human fetal membrane defects after fetoscopic surgery. Prenat Diagn, 36: 942-952. doi: 10.1002/pd.4917.

7 Drury S, Hywel W, Trump N, et al. Exome sequencing for prenatal diagnosis of fetuses with sonographic abnormalities. Prenat Diagn 2015;35:1010-17, DOI: 10.1002/pd.4675. 
8 Burger NB, Stuurman KE, Kok E, et al. Involvement of neurons and retinoic acid in lymphatic development: new insights in increased nuchal translucency. Prenat Diagn 2014;34:1312-19, DOI: $10.1002 / \mathrm{pd} .4473$.

9 Metcalfe A, Currie G, Johnson J-A, et al. Impact of observed versus hypothesized service utilization on the incremental cost of first trimester screening and prenatal diagnosis for trisomy 21 in a Canadian province. Prenat Diagn 2013;33:429-35, DOI: 10.1002/pd.4082.

10 Brinch $M$, Hatt $L$, Singh $R$, et al. Identification of circulating fetal cell markers by microarray analysis. Prenat Diagn 2012;32:742-51, DOI: 10.1002/pd.3894.

11 Pennings JLA, Kuc S, Rodenburg W, et al. Integrative data mining to identify novel candidate serum biomarkers for pre-eclampsia screening. Prenat Diagn 2011;31:1153-9, DOI: 10.1002/pd.2850.

12 Toutain J, Labeau-Gaüzere C, Barnetche T, et al. Confined placental mosaicism and pregnancy outcome: a distinction needs to be made between types 2 and 3. Prenat Diagn 2010;30:1155-64, DOI: $\underline{10.1002 / p d .2631 . ~}$

13 Chu T, Burke B, Bunce K, et al. A microarray-based approach for the identification of epigenetic biomarkers for the noninvasive diagnosis of fetal disease. Prenat Diagn 2009;29:1020-30, DOI: $10.1002 /$ pd.2335.

14 Picone O, Simon I, Benachi A, et al. Comparison between ultrasound and magnetic resonance imaging in assessment of fetal cytomegalovirus infection. Prenat Diagn 2008;28:753-8, DOI: $10.1002 / \mathrm{pd} .2037$.

15 Cowans NJ, Spencer K. First-trimester ADAM12 and PAPP-A as markers for intrauterine fetal growth restriction through their roles in the insulin-like growth factor system. Prenat Diagn 2007;27:264-71, DOI: $10.1002 / \mathrm{pd} .1665$.

This article is protected by copyright. All rights reserved. 


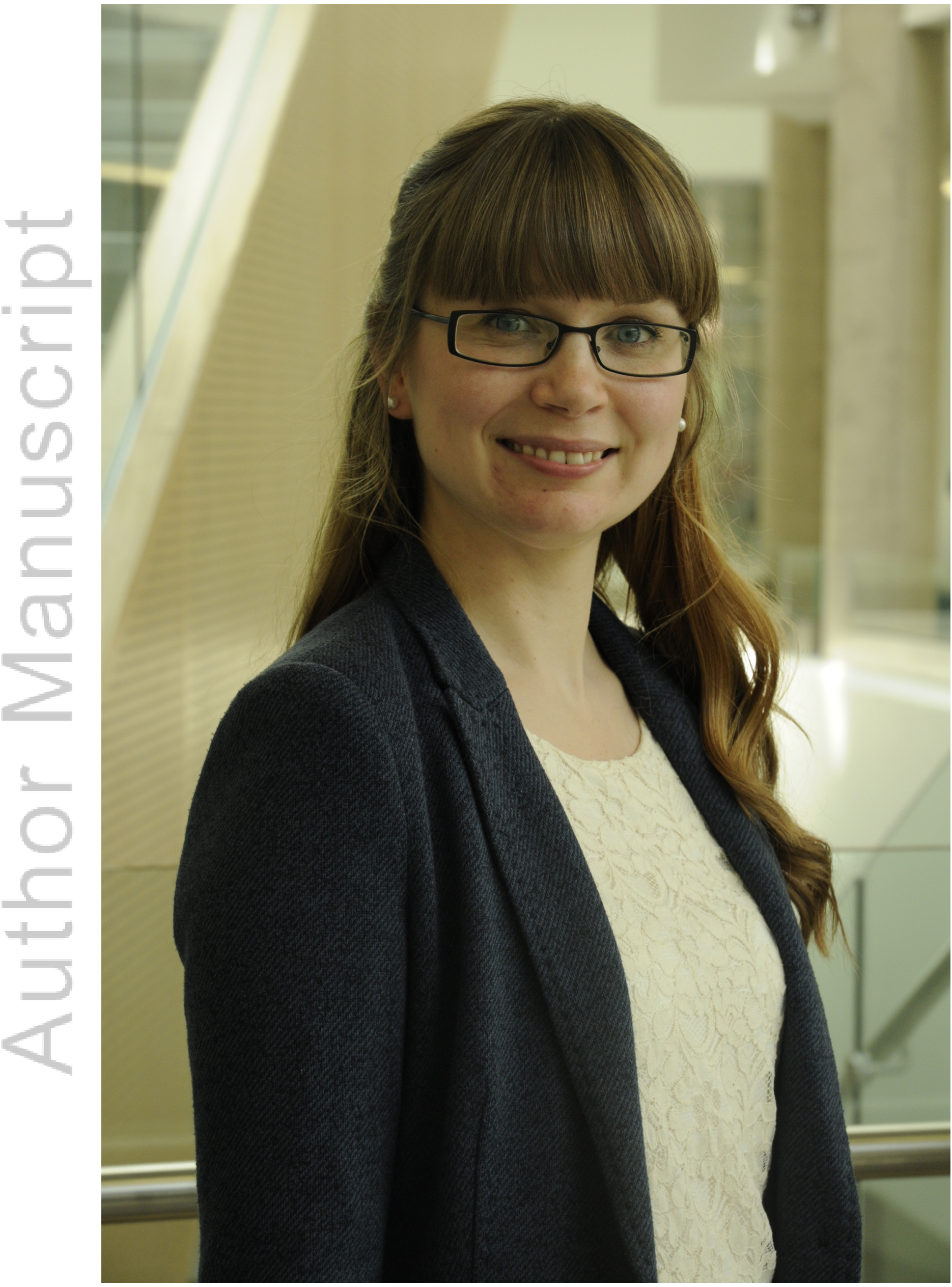

PD_5533_F1.jpg

This article is protected by copyright. All rights reserved. 


\section{University Library}

\section{- M M N E R VA A gateway to Melbourne's research publications}

Minerva Access is the Institutional Repository of The University of Melbourne

Author/s:

Bianchi, DW;Ghidini, A;Levy, B;Deprest, J;van Mieghem, T;Chitty, LS;Hui, L;McLean-Inglis, A

Title:

The 2018 Malcolm Ferguson-Smith Young Investigator Award

Date:

2019-08-15

Citation:

Bianchi, D. W., Ghidini, A., Levy, B., Deprest, J., van Mieghem, T., Chitty, L. S., Hui, L. \& McLean-Inglis, A. (2019). The 2018 Malcolm Ferguson-Smith Young Investigator Award. PRENATAL DIAGNOSIS, 39 (10), pp.835-837. https://doi.org/10.1002/pd.5533.

Persistent Link:

http://hdl.handle.net/11343/286271 